\title{
An examining the relationship between the trust in supervisors and interactional justice among the tourism employees
}

\author{
Pınar Çelik ${ }^{1}$ \\ Cengiz Gök ${ }^{2}$
}

\begin{abstract}
In recent years there has been a great increase in the number of researches dealing with trust in different disciplines. The reason of this increase is as modern societies become more and more complicated and disciplines pay more attention to reasons of human behaviour. One of the sectors that human behaviour has a vital and important role is tourism industry. Knowing the level of trust that employees have for their supervisors in tourism industry will help the enterprises to increase the level of their service quality and their effort to survive for along time in this competitive environment. When employees trust their supervisors, their added value to the enterprise will increase and they will contribute more to enterprise to reach its pre-set goals. In this study it is aimed to determine the level of trust that tourism employees have for their supervisors and possible results of trust level for the enterprise. In regression test made between trust in supervisor and interactional justice perception, trust in supervisor can be explained by interactional justice with $63 \%$.
\end{abstract}

Keywords: Trust; Interactional justice; Tourism enterprises.

\section{Introduction}

One of the most important factors of an enterprise is the employee. The employees' perspectives on their enterprises, their level of trust in their supervisors are the topics that different disciplines studied. As the contemporary business life gets more and more complicated the number of researches on employees' trust in their supervisors increases.

Enterprises try to continue their business life and make profit. In this process the most valuable and important element to use is the human resources, in other words the important element is employees. Employees should be managed effectively as well. If an enterprise aims to reach its goals it should provide a pleasant working atmosphere where the employees will feel themselves comfortable and also trustworthy colleagues whom the employees will respect and love (Tremens, 2002). Employees may show different attitudes to each other. Those attitudes may include; anger, trust, distrust and closeness (Cohen and Prusak, 2001). One of the most important factors that strengthen the relationship among the employees and the interaction with the supervisor is trust. It is not possible to expect an employee to contribute positively to the enterprise if there is a lack of trust. In other words if there isn't trust between the employees and the supervisor the aims of the enterprise will be affected negatively (Rosen, 1998). In addition to this it is emphasised by researchers that trust is a crucial element for enterprises to reach their targets. In

\footnotetext{
${ }^{1}$ Dr., Akdeniz University, Social Science Vocational School, pinarcelik@akdeniz.edu.tr

${ }^{2}$ Lecturer, Muğla Sıtkı Koçman University, Fethiye A.S.M.K. Vocational School, gokcengiz@,hotmail.com
} 
Çelik, P., \& Gök, C. (2016). A examining the relationship between the trust in supervisors and interactional justice among the tourism employees. Journal of Human Sciences, 13(3), 5998-6010. doi:10.14687/jhs.v13i3.4239

this context mutual trust among the employees and trust to supervisors play a vital role (Clarke, 2002).

Recently as the competition gets harder, trust became not only a human resource matter but also matter within the enterprises. Enterprises began to experience trust problems. If an enterprise is exposed to lack of trust among its employees and employees' lack of trust to their supervisors will be disadvantageous in its competitive advantage. Trust has a great importance to reach vital targets of an enterprise (Shaw, 1997). The level of trust that employees have towards their supervisors is considered among the very important factors which will affect their perception of the enterprise. If the employee's level of trust in their supervisor is known, the work environment will be set to more productive atmosphere for the employee and the enterprise will be able reach its pre-set goals.

The aim of the study is to determine the relationship between tourism employees' perception of interactional justice and trust in their supervisors.

\section{Literature Review}

Supervisor is a concept which is thought on very much and has many definitions how it should be. In classical view, anyone at an enterprise can be called as a supervisor who is believed his experience and skills and given authority because of his certain qualifications. However this definition is inadequate in contemporary times. The century we are in has brought new difficulties and some new qualifications that a supervisor should have. It is difficult to talk about possibly of someone become a supervisor who has a certain level of intelligence, experience and knowledge (Bayraktar, 2007). Nowadays to call a person as a supervisor that person should be professional and act in that way. Eren (2003) defines supervisor as person who gathers the production factors under changeable environment conditions in addition to reach pre-set aims.

Trust is a vital element for the enterprises to survive and be successful. When there is not trust in the enterprise sharing information and motivation will lack. If employees do not feel an atmosphere full of trust that company may suffer from valuable time loss money loss and many other valuable opportunities. Having an atmosphere shaped by trust will allow you to use valuable time for other actions rather than using it to check up on employees and others if they are cheating on you (Hurley and Siebers, 2007).

Trust is critical for every business. Trust is an important factor that everyone needs at different levels of their life. Trust first took its place among the studies in social psychology. Researchers studied how it stimulated the unity in the group or how it prevented the stimulation. In the following years different disciplines studied the trust (Hans, Werner and Bernd, 2004).

Trust requires a subject and an object, someone who trusts and someone who is trusted. Subject trusts the object. Object of the trust can be people, organizations, institutions, and socioeconomic systems. Someone's trust in other people in the enterprise is affected by the trust that he has for the enterprise. Trust in system will affect the trust in people and attitude towards them. Personal and systematically trust will affect each other mutually (Nooteboom, 2002).

It can be said that there are three different ways to continue a relationship. The first way is based on power. The relation between supervisors and the employees is mostly based on this. This relation based on carrot stick idea. However cost of control which stems from this relation is really high. Second type of relation is based on "hope" which stems from 90's Word "empowerment". This method let many enterprises down. There is another way to continue a relation that is trust based. In this type of relation people will do the things because they want to not just they have to or to reach the result. The most important feature of a trust based relation, which distinguishes it from others, is responsibility.

There is only one type of sanction in this type of relations, it is the trust. If trust fails the relation ends (Reynolds, 1997).

There are different subcategories about trust in the literature, for instance, behavioural, predictable and voluntary trust. The behavioural aspect of trust is not related with belief or 
Çelik, P., \& Gök, C. (2016). A examining the relationship between the trust in supervisors and interactional justice among the tourism employees. Journal of Human Sciences, 13(3), 5998-6010. doi:10.14687/jhs.v13i3.4239

cognitive situation. It mostly covers the behaviours, attitudes, trends that someone performs in the light of beliefs that a person has about himself or others. Predictable trust behaviour can simply be defined as conviction that a person has about someone else. In other words it can be defined as ability of predicting the behaviours. However, the emphasis here is on the predicting the others' behaviours. Voluntary trust is about leaving yourself into other person's hand voluntarily (Brenkert, 1998).

Even there seems to be a great consensus on how trust is important on human behaviours there is a big disagreement on its definition (Hosmer, 1995). Barney and Hanson (1994) defined trust as a mutual belief in which no one will take advantage of each other's vulnerability.

Some of other trust definitions can be listed as follows;

$>$ "It is belief of someone in the honesty, character, and ability of a leader." (Robins and Coulter, 1999)

$>$ "Mutual faith in one's objectives and behaviours."( Kreitner and Kinicki 1998)

$>$ "An intimate reliance on the integrity, openness, or justice of other person." (Landau, 1985).

Recent researches revealed that level of trust between the employees and supervisors shows difference due to two different variables. Those variables are; a) personal factors b) supervisor's behaviours. Personal factors mean characteristics features of a person and supervisor's behaviours mean the dynamics between the employee and the supervisor. Personal features include features affecting the trust level that they for their supervisors, those are; demographic features (age, sex etc.) personal traits (past experiences, personal and cultural background) and occupational competence in supervisor (supervisor's knowledge and skills). Different researchers claim that trust is established when there are similarities on demographic features between the supervisor and the employee. Many of the employees observe that if their supervisor has adequate knowledge to do his job, following their observation they decide to trust their supervisors or not to. Employees decide to trust their supervisors according to behaviours that they show in the interactions which the supervisors have with their employees (Whitener et.al., 1998).

Another common belief is that past experiences and chances of future interactions, both relevant within organisations can influence trust.

Past experiences of such behaviour will develop expectations of others' beneficial actions. If others experience the prior expectations, this good behaviour will develop positive expectations in the future. It will also enhance the level of trust between the actors. Actor will be more willing to co-operate (Lewicki and Bunker, 1996; Buskens, 1999; Gautschi, 2002).

Gabarro stated 9 components to achieve the trust. These are unity (honesty and moral character), instincts (intention), consistency (predictability), openness (being able to express the thoughts freely), cautiousness (ability to keep secret), sufficiency (certain knowledge and skills for a certain mission), interpersonal sufficiency (people's skills), job awareness, (general knowledge and intuition on how job is done) and judgment (ability to make good decisions) (Butler, 1991).

Both supervisors' and employees' attitudes, behaviours and features can contribute to interpersonal trust. Trust isn't a concept which emerges suddenly but gradually through out the time. In addition to this trust doesn't emerge alone itself, it emerges and develops in accordance with the quality of the relationship between the people. As the supervisor has more active position than the employee, supervisor's behaviours will affect the motivation of the employee who is in the interaction. Interaction process will begin with supervisor evaluating the employee's skills. Supervisor will be in some expectations according to employee's skills. If the supervisor decides the employee is trustworthy he will act according to that. As a result of this employee will perceive that his supervisor trusts him and he will respond to his supervisor in the same way. Following this process the employee will full fill the first expectation of his supervisor and the trust will continue to grow. It is quite clear that trust is a mutually developing process. This process is shown in the figure below (Broker et al. 2000). 
Çelik, P., \& Gök, C. (2016). A examining the relationship between the trust in supervisors and interactional justice among the tourism employees. Journal of Human Sciences, 13(3), 5998-6010. doi:10.14687/ihs.v13i3.4239

Supervisor's behaviour

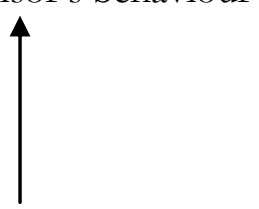

Supervisor's trust
Employee trust

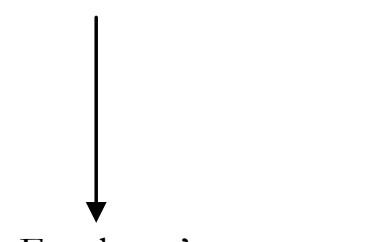

Employee's response

In today's competitive atmosphere if an enterprise have employees who trust to their supervisors it means that enterprise is one step ahead of its rivals. If you don't establish trust and make use of its benefits and reduce the cost one of your rivals will do it and leave you eliminate you. Trust is the key subject for today's enterprises. Thus it is vital for everyone in business world to understand the trust and create it (Reynolds, 1997).

When there is distrust at in an enterprise the following results may occur; descending commitment, low mood, high absenteeism, high labour turnover and excessive expenditure. The cost of distrust is higher than the benefits of trust (Diffie and Couch, 1984, edt. Mishra and Morrissey, 1990).

In an atmosphere where employees experience distrust they will hide the meaningful information and they will misdirect it. They hesitate to reveal their thoughts and ideas because they would believe they are vulnerable against others. All those will lead to misunderstanding and misinterpretation and will decrease the effect of group work and group problem solving efforts (Zand, 1972).

Today contemporary management takes human as its cornerstone and trust is the main actor of it. At enterprises experiencing high trust more responsibility and authority is given to the bottom line to provide team work and flexible work environment. When employees share the same ethic codes it will create an atmosphere where they will trust each other (Fukuyama, 2000). Distrust will lead employees to resist changes at the enterprises (Slater, 2000). Trust will minimize the cost of doing things (Cohen and Prusak, 2001). Employees working in an atmosphere without trust will not be able to be motivated. Their creative side will not be revealed (James, 1997).

In an organization organizational justice plays an important role for employees' personal satisfaction (Greenberg, 1990). Organizational justice is regarded as a concept that can have important results for both employees and organization (Gilliland and Chan, 2001).

Organizational justice stemmed from an attempt to describe the role of fairness in the workplace (Lemons and Jones, 2001). Organizational justice basically explains how individuals or groups perceive the fairness, honesty then their behaviour can be observed according the treatment they receive from the organization that they work for (Deutsch M, 1975)

Interactional justice which, is first stated by Robert J. Bies and Moag, is about the justice perception on communication between the employees and supervisors and/or employers. Robert J. Bies, defines interactional justice as the quality of attitudes and behaviours while organizational procedures are being conducted. (Atalay: 2002).

While researches on the distributive justice and procedural justice, interactional justice, deal with the interaction between the employees, organizational practices and management focusing on employees side, becomes subject to new researches. Interactional justice is about the humanitarian side of the organizational practices. It is based on kindness, honesty and respect during the process of relation between the source of the justice and receiver of the justice (Beugre, 2002). Interactional Justice will affect the employees' attitude towards their supervisors and to the enterprise as a whole where they work. When employees feel that they are not respected enough and they do not get enough explanation about the decisions made, they won't be willing to perform on their most. If such feeling covers the whole enterprise productivity might be in danger (Heather and Spence, 2004). 
Çelik, P., \& Gök, C. (2016). A examining the relationship between the trust in supervisors and interactional justice among the tourism employees. Journal of Human Sciences, 13(3), 5998-6010. doi:10.14687/jhs.v13i3.4239

It is possible to find different studies on trust and interactional justice in literature. Some of those studies are as follows and show how important those two topics. As Hurly and Siebers (2007), mentioned in their study trust plays a vital role for the organizations as they need it to be able to survive and to be able to be successful. Without trust there will be no idea sharing, innovation, job satisfaction and motivation. Lack of trust in organizations will lead to Money loss. Having trust will allow you to use the time allocated to understand that people do not cheat up on you for other useful actions. Reinke (2003), states that trust between the supervisor and employee is the main factor in accepting a new system. Similarly Condrey (1995) emphasises when an employee trusts his/her supervisor and enterprise he/she becomes more eager to be a part of the change. Trust in supervisors and organization will increase interpersonal trust and will lead to more information sharing. It will also help the employees to become more eager to make cooperation. Thus their performance will improve to a great extent. It is proved that trust has strong effect on organizational commitment, stress, productivity, information sharing and job satisfaction (Neves ve Caetano, 2006; Renzl, 2008).

Many supervisors believe that there is a lack of trust between supervisors and employees and they believe this is the one of the main reasons for ineffectiveness. A supervisor can order his/her employees however, the employees will never show their real performance if supervisors provide an environment full of trust (Mishra and Morrissey, 1990). Majority of the researchers didn't study interactional justice alone itself instead they studied under the title of procedural justice before Bies and Moag (1986), brought out the concept of interactional justice. In fact, as the studies on the interactional justice continued and increased it is revealed that there are important correlations and distinctions among distributive justice, procedural justice and interactional justice. Those justice types can be considered as the three dimensions of organizational justice. In the light of previous studies, Bies and Moag (1986) introduced the interactional justice. They stated that interactional justice was primarily dealt with the interaction ways among people. Interactional justice the shows how an employee perceives justice in the process procedure implementation would be influenced by the attitude of the executors towards them and how the executors treated them.

Empirical evidence gathered from the studies revealed that employees show much concern for the treatment they receive from supervisors and the adequacy with which formal decision making procedures are explained (Bies, Shapiro, \& Cummings, 1988). Regarding the norm of reciprocity, employees who believe they receive fair treatments by supervisors are more likely and willing to show positive actions through greater commitments to the values and goals of the organizations. Also they present increased job satisfaction, organizational citizenship behaviours, improved job performances and reduced withdrawal behaviours (Cohen-Charash and Spector, 2001; Colquitt et al., 2001).

\section{Methodology}

The aim of the study is to determine the relationship between tourism employees' perception of interactional justice and trust in their supervisors. In the study to determine the level of trust to the supervisor scale which is developed to evaluate the trust level for the supervisor is used. This scale was developed by Shelton (2005). In addition to this to determine the employees' perception level of interactional justice scale which is subcategory of organizational justice was used. It was developed by Niehoff and Moorman, (1993). A questionnaire is formed by the help of the scales mentioned above. The first part of the questionnaire is consisted of demographic questions; the second part is consisted of questions about interactional justice and trust in supervisors. Participants answered 9 questions about interactional justice and 14 questions about trust in supervisor. In the questionnaire 5 Likert scale questions are used (1: Totally agree, 5 : Totally disagree). Sample group was chosen as easy sampling. The questionnaire was conducted Fethiye in Mugla in May 2016. In total 112 questionnaires were reliable. Collected data was analysed by using SPSS 22. The following statistical analysis were used to exhibit to features of the sample group; Frequency, percentage, independent $t$ test, correlation analysis and regression analysis. 
Çelik, P., \& Gök, C. (2016). A examining the relationship between the trust in supervisors and interactional justice among the tourism employees. Journal of Human Sciences, 13(3), 5998-6010. doi:10.14687/ihs.v13i3.4239

\section{Results}

Cronbach's Alpha reliability was calculated for both interactional justice which is subcategory of organizational justice and trust in supervisor. Results showed that the number for interactional justice scale is $\alpha: 0,836$, and for the trust in supervisor scale is $\alpha: 0,887$. Those values prove that both scales have high reliability.

In ANOVA test results differences between the measurements are found statistically meaningful (Between Items $=0,000)$. Also it is found that in both question groups question mean differences are statically meaningful $(\mathrm{p}=$ Sig. $<0,01)$. The general mean for interactional organizational justice is calculated as 4,01 and for trust in supervisors is calculated as 3,99.

Table 1: Reliability test results of the scales

\begin{tabular}{|l|c|c|c|c|c|} 
& $\begin{array}{l}\text { Cronbach's } \\
\text { Alpha }\end{array}$ & $\begin{array}{c}\text { ANOVA with Tukey's Test for Nonadditivity } \\
\text { F }\end{array}$ & Sig & Hotelling's T-Squared Test \\
\hline $\begin{array}{l}\text { Organizational } \\
\text { Interaction Justice }\end{array}$ & 0,836 & 35,388 & 0,000 & 11,976 & 0,000 \\
\hline Trust in Supervisor & 0,887 & 13,139 & 0,000 & 5,869 & 0,000 \\
\hline
\end{tabular}

In Table 2 gender, education level, age, and working yea of 112 tourism employees are shown. Those 112 tourism employees formed the sample of the study.

Table 2: Quantative and Percentage Distribution of Sample Profile

\begin{tabular}{|c|c|c|c|c|c|c|c|}
\hline & & Value & Percentage & & & Value & Percentage \\
\hline \multirow[b]{2}{*}{ Gender } & Female & 31 & 27,7 & \multirow{5}{*}{ Working Year } & Less than 6 months & 39 & 34,8 \\
\hline & Male & 81 & 72,3 & & 6 months-1 year & 9 & 8,0 \\
\hline \multirow{5}{*}{ Age } & 25 and below & 49 & 43,8 & & 1-3 years & 13 & 11,6 \\
\hline & $26-30$ & 28 & 25,0 & & 3-5 years & 21 & 18,8 \\
\hline & $31-35$ & 18 & 16,1 & & $5+$ & 30 & 26,8 \\
\hline & $36-40$ & 7 & 6,3 & \multirow{5}{*}{$\begin{array}{l}\text { Working year } \\
\text { with the } \\
\text { supervisor }\end{array}$} & Less than 6 months & 44 & 39,3 \\
\hline & 41 and above & 10 & 8,9 & & 6 months- 1 year & 11 & 9,8 \\
\hline \multirow{4}{*}{ Education } & Primary School & 44 & 39,3 & & 1-3 years & 18 & 16,1 \\
\hline & High School & 41 & 36,6 & & 3-5 years & 11 & 9,8 \\
\hline & Associate & 11 & 9,8 & & $5+$ & 28 & 25,0 \\
\hline & Graduate & 16 & 14,3 & \multirow{5}{*}{$\begin{array}{l}\text { Satisfaction } \\
\text { with the } \\
\text { supervisor }\end{array}$} & Not at all satisfied & 57 & 50,9 \\
\hline \multirow{5}{*}{ Department } & Front office & 24 & 21,4 & & Slightly satisfied & 42 & 37,5 \\
\hline & $F \& B$ & 52 & 46,4 & & Moderately satisfied & 6 & 5,4 \\
\hline & Housekeeping & 26 & 23,2 & & Very satisfied & 1 & 0,9 \\
\hline & Technical Service & 4 & 3,6 & & Extremely satisfied & 6 & 5,4 \\
\hline & Accountancy & 6 & 5,4 & & & & \\
\hline
\end{tabular}

When table 2 is examined, sample group is formed by $27,7 \%$ female and $72,3 \%$ male employees. The age of the study group is mainly consisted of 25 year old and below with $43,8 \%$. Education level of the study group shows interesting data because 39,3\% of the group only completed their primary education, 36,3\% completed their high school education, $9,8 \%$ completed associate degree and only $9,8 \%$ of the study group completed their higher education. It is very remarkable that the higher education percentage is still very low among tourism employees. The percentage of their department is as follows; 46,4\% food and beverage, 23,2\% housekeeping, $21,4 \%$ front Office, $5,4 \%$ accountancy and 3,6\% technical service. When working is examined 
Çelik, P., \& Gök, C. (2016). A examining the relationship between the trust in supervisors and interactional justice among the tourism employees. Journal of Human Sciences, 13(3), 5998-6010. doi:10.14687/jhs.v13i3.4239

$34,8 \%$ stated that they work at their workplace less than six months and 39,3\% stated that they worked less than six months with the same supervisor. In addition to this $50,9 \%$ of the employees stated that they are totally satisfied with their supervisors.

Table 3: Mean and Standard Deviation of Interactional Justice Questions

\begin{tabular}{|c|c|c|}
\hline & Mean & $\begin{array}{l}\text { Std. } \\
\text { Deviation }\end{array}$ \\
\hline When decisions are made about my job, my supervisor treats me with respect and dignity & 4,33 & 0,842 \\
\hline When making decisions about my job, my supervisor offers explanations t hat make sense to me & 4,25 & 0,925 \\
\hline When decisions are made about my job, my supervisor deals with me in a truthful manner & 4,18 & 0,988 \\
\hline My supervisor explains very clearly any decisions made about my job & 4,18 & 0,970 \\
\hline When decisions are made about my job, my supervisor shows concern for my rights as an employee & 4,17 & 1,039 \\
\hline When decisions are made about my job, my supervisor is sensitive to my personal needs & 4,16 & 0,973 \\
\hline When decisions are made about my job, the supervisor treats me with kindness and consideration & 4,10 & 1,098 \\
\hline Concerning decisions made about my job, my supervisor discusses the implications of the decisions with me & 3,90 & 0,986 \\
\hline My supervisor never offers adequate justification for decisions made about my job & 2,82 & 1,330 \\
\hline
\end{tabular}

Results about Organizational Interactional Justice are presented in table 3. Table 3 shows the factors with the highest percentages are as follows; ". When decisions are made about my job, my supervisor treats me with respect and dignity" $(4,33)$, "When making decisions about my job, my supervisor offers explanationsthat make sense to me"(4,25), "When decisions are made about my job, my supervisor deals with me in a truthful manner" $(4,18)$. In table 3 the lowest percentage factors are "My supervisor never offers adequate justification for decisions made about my job $(2,82)$ and "Concerning decisions made about my job, my supervisor discusses the implications of the decisions with me. $(3,90)$.

Table 4: Mean and Standard deviation of Trust in Supervisor Questions

\begin{tabular}{|l|l|l|}
\hline My supervisor is open and upfront with me & Mean & $\begin{array}{l}\text { Std. } \\
\text { Deviation }\end{array}$ \\
\hline I can expect my supervisor to treat me in a consistent and predictable & 4,29 & 0,999 \\
\hline I believe that my supervisor observes the problems closely and shows adequate effort to solve them & 4,21 & 0,834 \\
\hline In general, I believe my supervisor's motives and intentions are good & 4,21 & 0,882 \\
\hline I believe my supervisor has high integrity & 4,18 & 0,997 \\
\hline My supervisor informs me about the topics and problems that I mentioned to him/her & 4,13 & 1,044 \\
\hline My supervisor values my ideas & 4,13 & 1,018 \\
\hline I believe my supervisors shows adequate reaction to employees' wrong behaviours & 4,08 & 1,179 \\
\hline My supervisor deals with my vocational education and development & $\mathbf{3 , 9 3}$ & 1,054 \\
\hline My supervisor discuses the decisions concerning my job & $\mathbf{3 , 9 0}$ & 0,986 \\
\hline I don't believe that my supervisor treats me fairly & $\mathbf{2 , 6 0}$ & 1,398 \\
\hline I am not sure if I fully trust my supervisor or not & $\mathbf{2 , 5 4}$ & 1,287 \\
\hline My supervisor isn't always honest and right & $\mathbf{2 , 3 5}$ & 1,250 \\
\hline I believe my supervisor backs up some of the employees & $\mathbf{2 , 2 2}$ & 1,206 \\
\hline
\end{tabular}

The results about trust in supervisor are given in table 4 . When table 4 is examined the items with the highest mean are respectively as follows; "I can expect my supervisor to treat me in a 
Çelik, P., \& Gök, C. (2016). A examining the relationship between the trust in supervisors and interactional justice among the tourism employees. Journal of Human Sciences, 13(3), 5998-6010. doi:10.14687/jhs.v13i3.4239

consistent and predictablefashion" (4,29), "My supervisor is open and upfront with me" (4,29), " I believe that my supervisor observes the problems closely and shows adequate effort to solve them " (4.21). The items with the least mean are respectively as follows; "I believe my supervisor backs up some of the employees" (2,22), " My supervisor isn't always honest and right" (2,35), " I am not sure if I fully trust my supervisor or not" $(2,54)$

Table 5: Correlation Table

\begin{tabular}{|c|c|c|c|c|}
\hline & \multicolumn{2}{|c|}{$\begin{array}{ll}\text { Organizational } & \\
\text { Interactional } & \text { Justice } \\
\text { (Interactional Justice } \\
\text { Scale) }\end{array}$} & \multicolumn{2}{|c|}{ Trust in Supervisor } \\
\hline & $\mathbf{r}$ & $\mathrm{p}$ & $\mathbf{r}$ & $\mathrm{p}$ \\
\hline Age & 0,149 & 0,117 & 0,070 & 0,466 \\
\hline Education & $-0,218^{*}$ & 0,021 & $-0,118$ & 0,215 \\
\hline Working year at the enterprise & $0,284^{* *}$ & 0,002 & $0,307^{* *}$ & 0,001 \\
\hline Working year with the same supervisor & $0,337^{* *}$ & 0,000 & $0,337^{* *}$ & 0,000 \\
\hline Satisfaction with the supervisor & $0,674^{* *}$ & 0,000 & $0,602^{* *}$ & 0,000 \\
\hline Interactional Justice & & & $0,790^{* *}$ & 0,000 \\
\hline
\end{tabular}

When table 5 examined a reverse meaningful relation is found between Interactional justice and education $(\mathrm{r}=-0,218 ; \mathrm{p} \leq 0,05)$. There is a same way meaningful relation between interactional justice and working year at the enterprise $(\mathrm{r}=0,284 ; \mathrm{p} \leq 0,01)$, working year with the same supervisor $(\mathrm{r}=0,337 ; \mathrm{p} \leq 0,01)$ and satisfaction with the supervisor $(\mathrm{r}=0,674 ; \mathrm{p} \leq 0,01)$

A meaningful same way relation is observed between trust in supervisor and working year at the enterprise $(r=0,337 ; p \leq 0,01)$, working year with the same supervisor $(r=0,337 ; p \leq 0,01)$, and satisfaction with the supervisor worked together $(\mathrm{r}=0,602 ; \mathrm{p} \leq 0,01)$ and organizational justice $(\mathrm{r}=0,790 ; \mathrm{p} \leq 0,01)$.

Table 6: Independent $\mathrm{T}$ test results on Gender

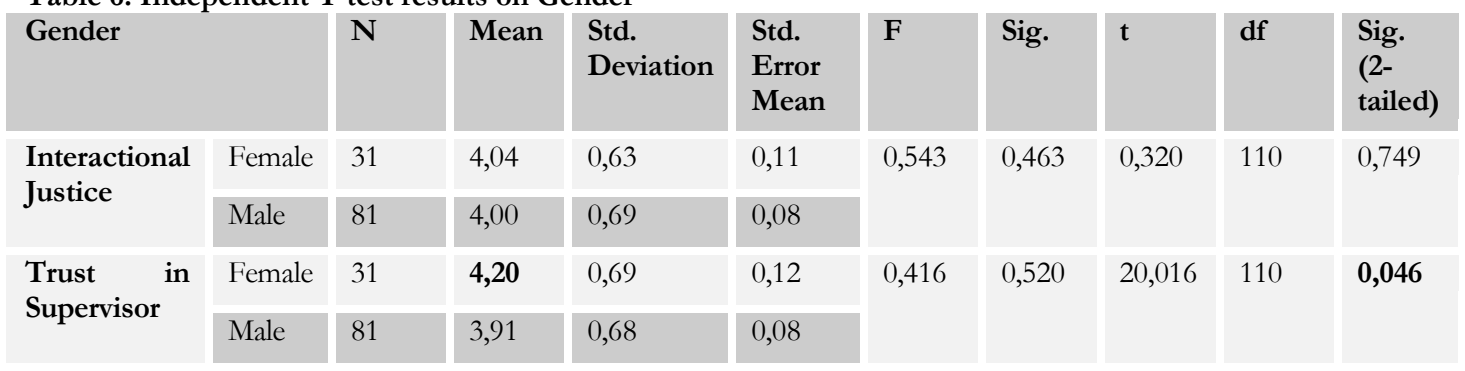

Table 6 shows gender distribution of the participants. According to the independent group $t$ test results there is not a meaningful statistical difference between the gender and the organizational (interactional) justice $\mathrm{p}=0,749>0,05)$, on the other hand a meaningful statistical difference between gender and trust in supervisor is observed $(p=0,046<0,05)$. It is clear that female employees $(4,20)$ trust their supervisors more than male employees $(3,91)$. 
Çelik, P., \& Gök, C. (2016). A examining the relationship between the trust in supervisors and interactional justice among the tourism employees. Journal of Human Sciences, 13(3), 5998-6010. doi:10.14687/jhs.v13i3.4239

Table 6: Anova Test results of Employees' perception of Organizational Justice

\begin{tabular}{|c|c|c|c|c|c|c|c|}
\hline & & $\mathbf{N}$ & Mean & $\begin{array}{c}\text { Std. } \\
\text { Deviation }\end{array}$ & df & $\mathbf{F}$ & Sig. \\
\hline \multirow{6}{*}{ Age } & 25 and below & 49 & 3,878 & 0,664 & \multirow{6}{*}{4} & \multirow{6}{*}{0,880} & \multirow{6}{*}{0,478} \\
\hline & $26-30$ & 28 & 4,103 & 0,713 & & & \\
\hline & $31-35$ & 18 & 4,105 & 0,615 & & & \\
\hline & $36-40$ & 7 & 4,063 & 0,693 & & & \\
\hline & 41 and above & 10 & 4,189 & 0,714 & & & \\
\hline & Total & 112 & 4,010 & 0,674 & & & \\
\hline \multirow{5}{*}{ Education } & Primary & 44 & 4,197 & 0,653 & \multirow{5}{*}{3} & \multirow{5}{*}{4,215} & \multirow{5}{*}{0,007} \\
\hline & High school & 41 & 3,992 & 0,626 & & & \\
\hline & Associate & 11 & 3,434 & 0,894 & & & \\
\hline & Graduate & 16 & 3,938 & 0,455 & & & \\
\hline & Total & 112 & 4,010 & 0,674 & & & \\
\hline \multirow{6}{*}{$\begin{array}{l}\text { Working } \\
\text { year at the } \\
\text { enterprise }\end{array}$} & Less than 6 months & 39 & 3,749 & 0,724 & \multirow{6}{*}{4} & \multirow{6}{*}{2,773} & \multirow{6}{*}{0,031} \\
\hline & 6 months -1 year & 9 & 3,914 & 0,807 & & & \\
\hline & $1-3$ year/s & 13 & 4,222 & 0,577 & & & \\
\hline & 3-5 years & 21 & 4,127 & 0,655 & & & \\
\hline & $5+$ & 30 & 4,204 & 0,524 & & & \\
\hline & Total & 112 & 4,010 & 0,674 & & & \\
\hline \multirow{6}{*}{$\begin{array}{l}\text { Working } \\
\text { year with } \\
\text { the same } \\
\text { supervisor }\end{array}$} & Less than 6 months & 44 & 3,684 & 0,720 & \multirow{6}{*}{4} & \multirow{6}{*}{5,132} & \multirow{6}{*}{0,001} \\
\hline & 6 months -1 year & 11 & 4,091 & 0,598 & & & \\
\hline & $1-3$ year/s & 18 & 4,327 & 0,559 & & & \\
\hline & $3-5$ years & 11 & 4,162 & 0,641 & & & \\
\hline & $5+$ & 28 & 4,226 & 0,507 & & & \\
\hline & Total & 112 & 4,010 & 0,674 & & & \\
\hline
\end{tabular}

Anova test results according to age, education, working year at the enterprise, working year with the same supervisor variables and interactional justice are given in Table 7. A meaningful statistical difference between age and interactional justice is not observed $(\mathrm{p}=0,478>0,05)$. There is a meaningful statistical difference between education and interactional justice perception $(\mathrm{p}=0,007<0,05)$. When the education is examined closely, it is clear that interactional justice perception is high among the employees who were graduated from primary school. In order to get more clear results Turkey t test is conducted, results showed that the difference is between primary school graduates and associate degree graduates $(p=0,04<0,05)$. There is a meaningful statistical difference in employees' interactional justice perception related to their working years. Employees who worked more than one year have more interactional justice perception than who worked less than a year. According to Turkey $t$ test this difference is observed between the employees who worked less than 6 months and who worked more than 5 years. There is a meaningful statistical difference between employees' working year with the same supervisor and interactional justice perception $(p=0,001<0,05)$. Employees who worked with the same supervisor have less interactional justice than the employees who worked with the same supervisor more than six months.

According the Turkey's $t$ test results this difference is seen between the employees who worked with the same supervisor less than 6 months and the employees who worked with the same 
Çelik, P., \& Gök, C. (2016). A examining the relationship between the trust in supervisors and interactional justice among the tourism employees. Journal of Human Sciences, 13(3), 5998-6010. doi:10.14687/jhs.v13i3.4239

supervisor between $1-3$ years $(\mathrm{p}=0,004<0,05)$, and between the employees who worked less than six months with the same supervisor and the employees who worked with the same supervisor 5 and up to 5 years $(\mathrm{p}=0,005<0,05)$.

Anova test results which are made according to and between ages, education, working year at the enterprise, working year with the same supervisor variables and the trust in supervisor are given in Table 8.

Table 7: Anova Test results of Employees' perception of Trust in Supervisors

\begin{tabular}{|c|c|c|c|c|c|c|c|}
\hline & & $\mathrm{N}$ & Mean & $\begin{array}{l}\text { Std. } \\
\text { Deviation }\end{array}$ & df & F & Sig. \\
\hline \multirow{6}{*}{ Age } & $\begin{array}{l}25 \quad \text { and } \\
\text { below }\end{array}$ & 49 & 3,908 & 0,733 & \multirow{6}{*}{4} & \multirow{6}{*}{0,640} & \multirow{6}{*}{0,635} \\
\hline & $26-30$ & 28 & 4,010 & 0,627 & & & \\
\hline & $31-35$ & 18 & 4,183 & 0,652 & & & \\
\hline & $36-40$ & 7 & 4,143 & 0,997 & & & \\
\hline & $\begin{array}{l}41 \\
\text { above }\end{array}$ & 10 & 3,900 & 0,552 & & & \\
\hline & Total & 112 & 3,992 & 0,695 & & & \\
\hline \multirow{5}{*}{ Education } & Primary & 44 & 4,119 & 0,678 & \multirow{5}{*}{3} & \multirow{5}{*}{1,784} & \multirow{5}{*}{0,154} \\
\hline & High school & 41 & 3,956 & 0,652 & & & \\
\hline & Associate & 11 & 3,591 & 0,749 & & & \\
\hline & Graduate & 16 & 4,009 & 0,762 & & & \\
\hline & Total & 112 & 3,992 & 0,695 & & & \\
\hline \multirow{6}{*}{$\begin{array}{l}\text { Working } \\
\text { year at the } \\
\text { enterprise }\end{array}$} & $\begin{array}{l}\text { Less than } 6 \\
\text { months }\end{array}$ & 39 & 3,769 & 0,670 & \multirow{6}{*}{4} & \multirow{6}{*}{3,280} & \multirow{6}{*}{0,014} \\
\hline & $\begin{array}{l}6 \text { months }-1 \\
\text { year }\end{array}$ & 9 & 3,611 & 0,780 & & & \\
\hline & $1-3$ year/s & 13 & 4,110 & 0,633 & & & \\
\hline & $3-5$ years & 21 & 4,116 & 0,668 & & & \\
\hline & $5+$ & 30 & 4,257 & 0,645 & & & \\
\hline & Total & 112 & 3,992 & 0,695 & & & \\
\hline \multirow{6}{*}{$\begin{array}{l}\text { Working } \\
\text { year with } \\
\text { the same } \\
\text { supervisor }\end{array}$} & $\begin{array}{l}\text { Less than } 6 \\
\text { months }\end{array}$ & 44 & 3,695 & 0,683 & \multirow{6}{*}{4} & \multirow{6}{*}{3,890} & \multirow{6}{*}{0,005} \\
\hline & $\begin{array}{l}6 \text { months }-1 \\
\text { year }\end{array}$ & 11 & 4,039 & 0,623 & & & \\
\hline & $1-3$ year/s & 18 & 4,143 & 0,462 & & & \\
\hline & $3-5$ years & 11 & 4,214 & 0,774 & & & \\
\hline & $5+$ & 28 & 4,255 & 0,701 & & & \\
\hline & Total & 112 & 3,992 & 0,695 & & & \\
\hline
\end{tabular}

According to results there is not a meaningful statistical difference between age and trust in supervisor $(p=0,635>0,05)$ and employees' education level and supervisor trust perception $(p=0,154>0,05)$. There is a meaningful statistical difference between employees' working year and trust in supervisor perception $(p=0,014<0,05)$. When the difference between working years is examined it is observed that the employees who worked with the same supervisor more than 1 year have higher trust in supervisor perception than the employees who worked less than a year. Turkey $\mathrm{t}$ test results revealed that this difference is only seen between the employees who worked less than 6 months and the employees who worked 5 and up to 5 years $(\mathrm{p}=0,0027<0,05)$. There is a meaningful statistical difference between the working year with the same supervisor and trust in 
Çelik, P., \& Gök, C. (2016). A examining the relationship between the trust in supervisors and interactional justice among the tourism employees. Journal of Human Sciences, 13(3), 5998-6010. doi:10.14687/jhs.v13i3.4239

supervisor perception $(p=0,005<0,05)$. When the difference in working year with the same supervisors examined the employees who worked less than 6 months have lower trust in supervisor perception than the employees who worked more than 6 months with the same supervisor.

Turkey's $t$ test results revealed that this difference is observed between the employees who worked less than 6 months with the same supervisor and the employees who worked 5 and up to 5 years with the same supervisor $(\mathrm{p}=0,006<0,05)$.

Table 8: Regression Analysis

\begin{tabular}{|c|c|c|c|c|c|c|c|c|}
\hline \multirow{3}{*}{ Anova } & & $\begin{array}{l}\text { Sum of } \\
\text { Squares }\end{array}$ & df & $\begin{array}{l}\text { Mean } \\
\text { Square }\end{array}$ & F & Sig. & $\mathrm{R}$ & R Square \\
\hline & Regression & 33,469 & 1 & 33,469 & \multirow{2}{*}{183,076} & \multirow[t]{2}{*}{, $000^{\mathrm{b}}$} & \multirow{6}{*}{0,79} & \multirow{6}{*}{,625 } \\
\hline & Residual & 20,110 & 110 & , 183 & & & & \\
\hline \multirow{4}{*}{ Model } & & \multicolumn{2}{|c|}{$\begin{array}{l}\text { Unstandardized } \\
\text { Coefficients }\end{array}$} & $\begin{array}{c}\text { Standardized } \\
\text { Coefficients }\end{array}$ & \multirow{2}{*}{$\mathrm{t}$} & \multirow{2}{*}{ Sig. } & & \\
\hline & & B & Std. Error & Beta & & & & \\
\hline & (Constant) & ,723 & ,245 & & 2,954 & ,004 & & \\
\hline & Justice & ,815 & ,060 & ,790 & 13,531 & ,000 & & \\
\hline
\end{tabular}

In regression test made between trust in supervisor and interactional justice perception, trust in supervisor can be explained by interactional justice with $63 \%$.

\section{Diccussion}

Many researches revealed that employees' trust in their supervisors has positive contributions to enterprise. It is possible to list them as follows; trust will provide a positive environment for the employees. When there is a high level of trust the employees will work at their best and quality of the products or service will be higher. The cost will decrease as the employees work with high motivation. The employees will benefit from this situation too. When they trust their supervisors the adaptation process will be quick and short. This will lead to better communication mutually. They will enjoy what they do and gain job satisfaction. They will be more careful, productive, motivated and devoted. They will achieve their goals and this will make the enterprise more powerful against its rivals. When employees believe that they are treated fair, their performance will be at the highest level. Their organizational commitment will be high. Employees will share their knowledge and create new knowledge if they trust in their supervisors.

As tourism industry relay on human relations trust among the employees and between the employees and their supervisors has a critical role in the success of a tourism industry. Having a trusted supervisor will relax the employees and they will be guided more easily by the supervisor. Employees will be more eager to cooperate and they will be focusing on solution if there is a problem. Also when they have a trusted supervisor the quality of the service that they provide will be better. The labour turnover level will decrease and cost of employee will be less. As above mentioned if an enterprise has an employees working for it for a long time the trust level will rise. The enterprise will have a powerful side against its rivals. It will be able to compete with them easily in a risky and powerful competitive environment. 
Çelik, P., \& Gök, C. (2016). A examining the relationship between the trust in supervisors and interactional justice among the tourism employees. Journal of Human Sciences, 13(3), 5998-6010. doi:10.14687/jhs.v13i3.4239

\section{REFRECES}

Atalay, D. (2002). Örgütsel Vatandaşlık ve Örgütsel Adalet, Yayınlanmamış Yüksek Lisans Tezi, Kocatepe Üniversitesi SBE, Afyon.

Bayraktar, B. B. B., (2007), 21. Yürynl Bilgi Yöneticisi, Özellikleri, Rol ve Becerileri, Yetkinlikleri ve Alskkanliklarr. İstanbul, Beta Yayınları.

Beugre, C. D. (2002), "Understanding Organizational Justice and Its Impact on Managing Employees: An African Perspective", The International Journal of Human Resource Management, November, 13 (7).

Bies, R. J., Shapiro, D. L., and Cummings, L. L. (1988). Causal accounts and managing organizational conflict: Is it enough to say it's not my fault?. Communication Research, 15, 381 399.

Bies, R. J. and Moag, J. S. (1986) Interactional Justice: Communication Criteria of Fairness. Research on Negotiation in Organizations, 1, 43-55.

Brenkert, G. G. (1998). Trust, Morality, and International Business. C. Lane and R. Bachmann (Ed.). Trust Within And Between Organizations: Conceptual Issues And Empirical Applications.

Broker, H. H., Schoorman, F. D. and Tan, H. H. (2000). "A model of relational leadership: The integration of trust and leader-member exchange". Leadership Quaterly,11, pp. 227-250.

Buskens, V. W. (1999). Social Networks and Trust, Thela Thesis, Amsterdam.

Butler, J. K. (1991). Toward Understanding And Measuring Conditions Of Trust: Evolution Of Conditions Of Trust Inventory. Journal of Management, 17.3, 643-663.

Clarke, J. (2002). Maymuncuk. MESS Yayınları, İstanbul

Cohen, D. \& Prusak, L. (2001). Kavrayamadığmmı Zenginlik, Kuruluşlarn Sosyal Sermayesi. İstanbul, MESS Yayinları.

Cohen-Charash, Y., and Spector, P. E. (2001). The role of justice in organizations: Ameta-analysis. Organizational Behavior and Human Decision Processes, 86(2),278-321.

Colquitt, J. A., Conlon, D. E., Wesson, M. J., Porter, C. O. L. H., and Yee Ng, K. (2001). Justice at the millennium: A meta-analytic review of 25 years of organizational justice research. Journal of Applied Psychology, 86, 425-445.

Condrey, S. E. (1995). Reforming human resource management systems: exploring the importance of organizational trust. American Review of Public Administration, 25(4), pp. 341-354.

Desk Dictionary. USA: Harper \& Row Publishers Inc.

Desk Dictionary. USA: Harper \& Row Publishers Inc.

Deutsch, M. (1975). Equity, equality and need: what determines which value will be used as the basis for distributive justice?. Journal of Social Issues, 31, 137-149.

Diffie-Couch, P. (1984). Building A Feeling Of Trust In The Company. Supervisory Trust, 29.4, 3136.

Eren, E. (2003). Yönetim ve Organizasyon, Beta Yayım Dağıtım A.Ş., Yayın No: 1067, 6.Basım, İstanbul.

Fukuyama, F. (1995). Trust - The Social Virtues and the Creation of Prosperity, Harmondsworth, Middlesex, Penguin Books.

Gautschi, T. (2002). Trust and Exchange: Effects of Temporal Embeddedness and Network Embeddedness on Providing a Surplus, Thela Thesis, Amsterdam.

Gilliland, S. W. and Chan, D. (2001). Justice in organizations: Theory, methods, and applications. In: NA Anderson, DS Ones, HK Sinangil and C Viswesvaran (Eds.). Handbook of Industrial, Work and Organizational Psychology (pp. 143-165), London: Sage Publications.

Greenberg, J. (1990). Organizational justice: Yesterday, today, tomorrow. Journal of Management 16(2), 399-432.

Hans-Werner, B. and V. Bernd. (2004). The Social Psychology of Trust With Applications in the Internet, Analyse und Kritik, Wiesbaden, 26.1, 48-63.

Heather, K., and Spence, L., (2004). "Hospital Nurses: Perceptions of Respect and Organizational Justice", JONA, 34, (7/8). 
Çelik, P., \& Gök, C. (2016). A examining the relationship between the trust in supervisors and interactional justice among the tourism employees. Journal of Human Sciences, 13(3), 5998-6010. doi:10.14687/ihs.v13i3.4239

Hosmer, L. T. (1995). Trust: The Connecting Link Between Organizational Theory And Philosophical Ethics. The Academy Of Management Review, 20.2, 379-403.

Hurley, P. and Siebers, J. (2007). Companies Without Trust Will Fail To Thrive. Strategic Communication Management. 11.4,7.

İslamoğlu, G., Birsel M. and Börü D., (2007). Kurum İ̧inde Güven. Birinci Baskı. İstanbul: İnkılap Kitabevi.

Jennifer, J., (1997). Gelecek Zamanda Düş̈̈nmek. İstanbul. Boyner Yayınları.

Kreitner, R. and Kinicki A., (1998). Organizational Behavior (4th ed.), Irwin McGraw-Hill.

Landau, S. I. (1984). Funk and W agnall's standard desk dictionary. New York: Harper \& Row Publishers Inc.

Landau, S. I. (Ed.). (1984). Funk and Wagnall's Standard

Landau, S. I. (Ed.). (1984). Funk and Wagnall's Standard

Lemons, M. A. and Jones, C. A. (2001). Procedural justice in promotion decisions: Using Perceptions of Fairness to Build Employee Commitment. Journal of Managerial Psychology, 16, 268-280.

Lewicki, R. J. and Benedict, B. (1996). Developing and maintaining trust in work relationships. in Kramer, R. M. and Tyler, T. R. (Eds), Trust in Organizations, Sage, Thousand Oaks, CA, pp. 114-39.

Mishra, J. and Morrissey, M. A. (1990). Trust İn Employee/Employer Relationships: A Survey Of WestMichigan Managers. Public Personnel Management, 19.4, 443-485.

Neves, P. and Caetano, A., (2006). Social Exchange Processes in Organizational Change: The Role ofTrust and Control. Journal of Change Management, 6.4, 351-364.

Niehoff, B. P., \& Moorman, R. H. (1993). Fairness in performance monitoring: The role of justice in mediating the relationship between monitoring and organizational citizenship behaviors. Academy of Management Journal, 36, 527-556.

Nooteboom, B. (2002). Trust: Forms, Foundations,Functions, Failures And Figures. Cheltenham: Edward Elgar Publishing.

Reinke, S. J. (2003). Does the form really matter? Leadership, trust, and the acceptance of the performance appraisal process. Revien of Public Personnel Administration, 23(1), pp. 23-37.

Renzl, B. (2006). Trust In Management and Knowledge Sharing: The Mediating Effects Of Fear andKnowledge Documentation. The International Journal Of Management Science, 36, 206-220.

Reynolds, L. (1997). The Trust Effect: Creating The High Trust High Performance Organization. London: Nicholas Brealey Publishing.

Robbins, S. P. and Coulter, M. (1999) Management (6th ed.), Prentice Hall.

Rosen, H. Robert. (1998). İnsan Yönetimi. (Çev. Gündüz Bulut), İstanbul:MESS Yayınları.

Shaw, R. B. (1997). Trust in the Balance: Building Successful Organizations on Results, Integrity and Concern, Jossey-Bass Publishers, San Francisco, CA.

Shelton, S. T., (2005), Employee Trust in Supervisor Measurement Instrument Development, Southern Political Science Association Conference, New Orleans, LA., January 6-8.

Slater, R., and Welch J., (2000). General Electric'in Yolu Efsane GEO'nun Yönetim Anlayısı ve Liderlik Sirlar.(Çev. Türkan Arıkan, Saadet Özkal), İstanbul: Literatür Yayıncilık.

Whitener, E. M., Brodt, S. E., Korsgaard M. A. and Werner, J. M. (1998). Managers asinitiators of trust: An exchange relationship framework for understanding managerial trustworthy behaviour. Academy of Management Review, 23, pp. 513-530.

Zand, D. E. (1972). Trust and Managerial Problems Solving. Administrative Science Quarterly, 17. 2, 229-239. 